\title{
KINETIKA REAKSI TRANSESTERIFIKASI MINYAK BIJI KETAPANG (Terminalia Catappa L) PADA PROSES PRODUKSI METIL ESTER
}

\section{THE KINETICS OF THE TRANSESTERIFICATION REACTION OF KETAPANG OIL SEEDS (Terminalia catappa L) OF METHYL ESTER PRODUCTION PROCESS}

\author{
Harun Al-Rasyid ${ }^{1}$, Rahmad Nasir ${ }^{2}$ \\ ${ }^{1}$ IKIP Muhammadiyah Maumere, Nusa Tenggara Timur, Indonesia \\ ${ }^{2}$ STKIP Muhammadiyah Kalabahi, Nusa Tenggara Timur, Indonesia \\ *Email: Aroenrasyid6@gmail.com.
}

Diterima: 29 Oktober 2019. Disetujui: 8 Januari 2020. Dipublikasikan: 31 Januari 2020

\begin{abstract}
Abstrak: Telah dilakukan penelitian tentang kinetika reaksi transesterifikasi minyak biji ketapang (Terminalia Catappa L) pada proses produksi metil ester menggunakan ekstraksi sokletasi. Buah biji ketapang dihaluskan dan disokletasi beberapa gram sampel menggunakan pelarut petroleum benzen. Ekstraksi dilanjutkan dengan destilasi untuk mendapatkan minyak ketapang murni. Katalis yang digunakan dalam pembuatan biodiesel ini adalah $\mathrm{KOH}$ dengan konsentrasi katalis $0,5 \% \mathrm{~b} / \mathrm{b} \mathrm{KOH} /$ minyak biji ketapang. Pelarut yang digunakan adalah metanol dengan rasio molar terhadap minyak biji ketapang 6:1. Kinetika reaksi transesterifikasi diteliti dengan mengambil $50 \mathrm{ml}$ sampel dari labu leher tiga dengan selang waktu (10, 20, 30, 40, 50 dan 60 menit) pada temperatur $30{ }^{\circ} \mathrm{C}$ dan kecepatan pengadukan $2140 \mathrm{rpm}$. Sampel dituang dalam botol yang telah disi $50 \mathrm{ml}$ air dan didiamkan dalam lemari es pada suhu $20{ }^{\circ} \mathrm{C}$ selama 24 jam. Metil ester kemudian dipisahkan dari gliserol dan air dengan menggunakan corong pisah kemudian cuci menggunakan $\mathrm{NaSO}_{4}$ dengan tujuan mengikat air yang masih terkandung dalam metil ester tersebut. Metil ester murni selanjutnya dianalisis dengan GCMS untuk mengetahui kandungan metil ester dan HNMR untuk menghitung kinetika reaksi transesterifikasi minyak biji ketapang untuk suhu $30{ }^{\circ} \mathrm{C}$. Hasil penelitian menunjukan waktu yang ideal pada proses produksi metil ester untuk suhu $30^{\circ} \mathrm{C}$ adalah menit ke 60 dengan kinetika reaksi pada orde 2 yang pada grafiknya paling tinggi dan persamaan laju reaksi transesterifikasi minyak biji ketapang menjadi metil ester adalah $r=k[T G]^{2}$
\end{abstract}

Kata Kunci : kinetika reaksi, transesterifikasi, minyak biji ketapang, metil ester

\begin{abstract}
Has done a research about kinetics of the transesterification reaction of ketapang seeds oil (Terminalia catappa l) of methyl ester production process using sokletation extraction. The ketapang seeds oil had been dissolved and then the several gram of sample were solektated using petroleum benzene solvent. Extraction followed by distillation to obtain pure ketapang oil. The catalyst used in the manufacture of biodiesel is the $\mathrm{KOH}$ with catalyst concentration $0.5 \% \mathrm{~b} / \mathrm{b} \mathrm{KOH} /$ ketapang seed oil. The solvent used was methanol with molar ratio of ketapang seed oil was 6:1. The kinetics of the transesterification reaction studied by taking $50 \mathrm{ml}$ samples of the three-neck flask with a time interval $(10,20,30,40,50$ and $60 \mathrm{~min})$ at a temperature of $30^{\circ} \mathrm{C}$ and a stirring speed of $2140 \mathrm{rpm}$. Sample is poured in the bottles that had been poured of $50 \mathrm{ml}$ of water and allowed to stand in a refrigerator at a temperature of $20^{\circ} \mathrm{C}$ for 24 hours. Methyl esters are then separated from the glycerol and water using a separating funnel and wash using a $\mathrm{NaSO}_{4}$ in order to in the water which still contained the methyl ester. Pure methyl esters then were analyzed by GCMS to determine the content of methyl ester and HNMR to calculate the kinetics transesterification reaction of ketapang seed oil to a temperature of 30 ${ }^{\circ} \mathrm{C}$. The results showed that the ideal time to process for production of methyl ester for temperature $30^{\circ} \mathrm{C}$ is 60 min with the kinetics of the reaction on orde 2 that are the highest graphics and the equation transesterification reaction rate ketapang seed oil into methyl ester is $r=k[T G]^{2}$
\end{abstract}

Keywords: kinetics of the reaction, transesterification, ketapang seed oil, methyl ester

\section{Pendahuluan}

Indonesia merupakan salah satu negara penghasil minyak bumi di dunia, tetapi sampai saat ini masih mengimpor bahan bakar minyak (BBM) untuk mencukupi kebutuhan bahan bakar minyak.
Kebutuhan bahan bakar minyak dalam negeri meningkat seiring meningkatnya pembangunan. Sejumlah laporan menunjukkan sejak pertengahan tahun 80-an terjadi peningkatan kebutuhan energi khususnya untuk bahan bakar 
mesin diesel yang diperkirakan akibat meningkatnya jumlah industri, transportasi dan pusat Pembangkit Listrik Tenaga Diesel (PLTD) di berbagai daerah di Indonesia. Seiring dengan peningkatan kebutuhan bahan bakar, cadangan minyak yang dimiliki indonesia semakin terbatas karena merupakan produk yang tidak dapat diperbaharui. Salah satu solusi yang digunakan untuk mengatasi masalah ini yaitu melakukan usaha-usaha untuk mencari bahan bakar alternatif seperti biodiesel.

Pengertian ilmiah paling umum dari istilah "biodiesel" mencakup sembarang (dan semua) bahan bakar mesin diesel yang terbuat dari sumber daya hayati atau biomassa. Sekalipun demikian pengertian lebih sempit yang telah diterima di dalam bidang industri, yaitu bahwa biodiesel adalah bahan bakar mesin atau motor diesel yang terdiri atas ester alkil dari asam-asam lemak [1].

Biodiesel dapat dibuat dari minyak nabati maupun lemak hewan, namun yang paling umum dugunakan sebagai bahan baku pembuatan biodiesel adalah minyak nabati. Minyak nabati dan biodiesel tergolong ke dalam kelas besar senyawa-senyawa organik yang sama, yaitu kelas asam-asam lemak. Akan tetapi minyak nabati adalah asam-asam lemak dengan gliserol, atau trigliserida, sedangkan biodisel adalah mono ester asam-asam lemak dengan metanol.

Dewasa ini, sebagian besar pembuatan biodiesel dari proses transesterifikasi sumber minyak nabati, seperti lemak hewan, minyak sayur, dan bahkan limbah minyak goreng, dengan proses katalis basa. Namun, konsumsi tinggi katalis, pembentukan sabun, dan rendahnya hasil panen membuat biodisel saat ini lebih mahal daripada bahan bakar yang diproduksi dari minyak bumi [2].

Terminalia catappa $L$ secara luas ditanam di daerah tropis dan subtropis di seluruh wilayah dunia. Di Indonesia pohon Terminalia catappa $L$ tumbuh liar di dataran rendah dan sering dijumpai di daerah pesisir pantai. Tumbuhan ini juga dapat tumbuh pada dataran tinggi. Terminalia catappa $L$ merupakan tumbuhan multiguna.

Biji Terminalia catappa L. mengandung minyak sebesar $40,15 \%$, sehingga minyak dari buah biji ketapang yang diperoleh melalui proses esterifikasi dapat diubah menjadi ester melalui proses tranesterifikasi [3]. Proses transesterifikasi digunakan untuk mengubah minyak dasar menjadi ester yang diinginkan dan membuang asam lemak bebas. Setelah melewati proses transesterifikasi, biodiesel memiliki sifat pembakaran yang mirip dengan diesel (solar) dari minyak bumi. Minyak biji ketapang memiliki prospek untuk dijadikan suatu pilihan baru dalam industri minyak nabati dan berpeluang untuk digunakan sebagai minyak pangan dan bahan baku industri sabun, lilin dan minyak pelumas [4].

Beberapa metode yang pernah digunakan untuk memperoleh fatti acid methyl ester (FAME) dari trigliserida diantaranya transesterifikasi dengan katalis basa atau asam serta penggunan enzim [5]. Dalam penelitian ini mereaksikan minyak biji ketapang dengan metanol menggunakan katalis $\mathrm{KOH}$.

Kinetika reaksi transesterifikasi untuk minyak nabati sudah diteliti oleh beberapa peneliti. Freedman dan kawan-kawan meneliti kinetika reaksi transesterifikasi minyak kedelai dengan methanol dan butanol, yang dikatalis oleh asam dan basa. Banyak peneliti yang sudah meneliti tentang kinetika reaksi reaksi transesterifikasi dari minyak nabati, kinetika reaksi transesterifikasi berbahan minyak mentah dedak padi [6]. Kinetika reaksi transesterifikasi berbahan minyak biji nyamplung dan masih banyak lagi peneliti yang meneliti tentang kinetika reaksi transesterifikasi dari minyak bumi, tetapi penelitian kinetika reaksi transesterifikasi minyak biji ketapang (Terminalia Catappa L) menjadi metil ester sejauh ini belum dilakukan [7]. Laju reaksi tranesterifikasi juga sangat dipengaruhi oleh suhu reaksi. Reaksi transesterifikasi dapat berlangsung sempurna pada suhu kamar dengan waktu reaksi yang cukup lama. Umumnya suhu reaksi yang terjadi mengikuti suhu didih methanol $\left(60^{\circ} \mathrm{C}-70{ }^{\circ} \mathrm{C}\right)$ pada tekanan atmosferik [8]. Dari uraian di atas, maka perlu untuk dilakukan penelitian tentang kinetika reaksi transestrifikasi minyak biji ketapang (Terminalia Catappa L) pada proses produksi metil ester.

\section{Metode Penelitian}

\section{Bahan dan Alat}

Bahan: minyak biji ketapang (Terminalia catappa), metanol, $\mathrm{KOH}$ Kristal, aquadest, natrium sulfat,dan petroleum bensen

Alat-alat: alat-alat gelas, thermometer, pengayak 100-120 mesh, lumpang porselin dan penggerus, oven (Fisher scientific), furnace kolom, kertas saring Whatman 42, timbangan digital (Denver), pompa air, pengaduk magnetic, corong pisah, saringan, Erlenmeyer, pH meter, gelas ukur, incubator, thermometer, penangas parifin, alat destilasi, alat refluks, neraca, dan alat GC-MS serta H-NMR.

\section{Prosedur Penelitian}

Penyiapan Sampel

Sampel yang diteliti adalah minyak dari biji ketapang. Ketapang dikeringkan kemudian 
diambil bijinya dengan cara dibelah, dan dihaluskan

\section{Ekstraksi biji buah ketapang}

Ekstraksi adalah pemisahan satu atau beberapa bahan dari suatu padatan atau cairan dengan bantuan pelarut. Ekstraksi juga merupa kan proses pemisahan komponen dari suatu campuran homogen menggunakan pelarut cair (solven). Pemisahan terjadi atas dasar kemam- puan kelarutan yang berbeda dari komponen-komponen dalam campuran [9].

Ada suatu jenis pemisahan lainnya dimana satu fase dapat berulang-ulang dikontakkan dengan fase yang lain, misalnya ekstraksi berulang-ulang suatu larutan dalam pelarut air dan pelarut organik. Proses pemi- sahan ini menggunakan suatu metode yang disebut dengan metode ekstraksi soxhlet. Metode ekstraksi soxhlet adalah suatu metode ekstraksi bahan yang berupa padatan dengan solven berupa cairan secara kontinu. Peralatan yang digunakan dinamakan ekstraktor soxhlet.

Sampel biji buah ketapang dihaluskan kemudian ditimbang sebanyak 100 gram, kemudian dibungkus dengan kertas saring dan diekstraksi dengan menggunakan ekstraksi soxhletasi. Pelarut yang digunakan adalah petroleum bensen $500 \mathrm{ml}$. Proses ekstraksi dihentikan ketika semua biji ketapang terekstraksi oleh pelarut dan untuk mendapatkan minyak biji ketapang bebas pelarut dilanjutkan dengan proses destilasi atau evaporasi dan pengeringan dengan menambahkan 5 gram natrium sulfat anhidrat, kemudian disaring.

\section{Transesterifikasi Minyak Biji Ketapang}

Transesterifikasi minyak biji ketapang dengan rasio molar metanol terhadap minyak biji ketapang 6:1 dan konsentrasi katalis $0,5 \% \mathrm{~b} / \mathrm{b}$ $\mathrm{KOH} /$ minyak biji ketapang, dilakukan dengan menimbang $300 \mathrm{~mL}$ minyak biji ketapang bebas air dalam labu leher tiga. Larutan kalium metoksida dibuat dengan cara melarutkan 2,5 gram p.a $(0,5 \%$ b/b KOH/minyak biji ketapang) dalam $282 \mathrm{~mL}$ methanol, diaduk sampai semua $\mathrm{KOH}$ larut, kemudian dituang ke dalam labu leher tiga yang sudah diisi minyak biji ketapang dan mulai mencatat waktu. Kecepatan pengadukan $2140 \mathrm{rpm}$ dan temperatur $30^{\circ} \mathrm{C}$ dijaga konstan.

Diambil $50 \mathrm{~mL}$ sampel dari dalam labu leher tiga pada selang waktu tertentu $(10,20,30,40$, 50 dan 60 menit) selama proses transesterifikasi dan segera dituang ke dalam botol yang telah diisi $50 \mathrm{~mL}$ air destilasi (aquades) untuk menghentikan reaksi. Waktu reaksi untuk sampel tersebut adalah sampai sampel dituang ke dalam botol sampel. Kemudian sampel dimasukkan ke dalam lemari pendingin (lemari es) pada suhu $-20{ }^{\circ} \mathrm{C}$,sampai perlakuan lebih lanjut. Lapisan metil ester dan lapisan air dipisahkan dengan cara sampel yang sudah didinginkan dimasukan dalam corong pisah dan didiamkan selama 24 jam, kemudian jika sudah terbentuk dua lapisan kemudian dipisahkan. Lapisan metil ester diambil dengan pipet dan ditempatkan dalam botol kosong yang bersih dan kering kemudian dikeringkan dengan natrium sulfat anhidrat untuk menghilangkan sisa air yang masih ada, kemudian di saring.

\section{Analisis Produk Transesterifikasi}

Komposisi masing-masing sampel metil ester minyak biji ketapang dianalisis dengan GC-MS. Persentasi konversi metil ester dianalisis dengan ${ }^{1} \mathrm{H}-\mathrm{NMR}(60 \mathrm{~Hz})$. Konversi metil ester (\%) dihitung menggunakan persamaan 1 [10].

$$
\mathrm{C}_{\mathrm{ME}}(\%)=100 \times \frac{5 I_{M E}}{5 I_{M E+9 I_{T G}}}
$$

di mana $\mathrm{C}_{\mathrm{ME}}=$ konversi metil ester $(\%), \mathrm{I}_{\mathrm{ME}}=$ nilai integrasi puncak metil ester $(\%)$ dan $\mathrm{I}_{\mathrm{TG}}=$ nilai integrasi puncak trigliserida $(\%)$, faktor 5 dan 9 adalah jumlah proton yang terdapat pada gliseril dalam molekul trigliserida mempunyai 5 proton dan tiga molekul metil ester yang dihasilkan dari satu molekul trigliserida mempunyai 9 proton. Persentase TG yang masih ada dalam produk dapat ditentukan dengan persamaan 2 .

$$
\mathrm{C}_{\mathrm{TG}}(\%)=100-\mathrm{C}_{\mathrm{ME}}
$$

Dimana $\mathrm{C}_{\mathrm{TG}}=$ trigliserida yang tidak terkonversi, \%. Data $\mathrm{C}_{\mathrm{ME}}$ hasil analisis dari sampel hasil masing-masing proses diisi pada tabel 1 .

Tabel 1. Format tabel untuk pengisian data $C_{M E}$ dan hasil $\mathrm{C}_{\mathrm{TG}}$ masing-masing proses, dengan variasi waktu reaksi.

\begin{tabular}{|c|c|c|}
\hline \multirow{3}{*}{$\begin{array}{c}\text { Waktu } \\
\text { (menit) }\end{array}$} & $\begin{array}{c}\text { Kadar metil } \\
\text { ester (C) }\end{array}$ & $\begin{array}{c}\text { C } \\
\text { TG }=100-\mathrm{C}_{M E} \\
(\%)\end{array}$ \\
\hline 10 & $301 \mathrm{~K}$ & $301 \mathrm{~K}$ \\
\hline 20 & & \\
\hline 30 & & \\
\hline 40 & & \\
\hline 50 & & \\
\hline 60 & & \\
\hline
\end{tabular}

Kinetika reaksi dikaji dengan cara menguji data $\mathrm{C}_{\mathrm{ME}}$ atau $\mathrm{C}_{\mathrm{TG}}$ pada persamaan hasil integrasi untuk masing-masing orde $0,1,2$ dan 3 melalui metode regresi linear. Grafik yang menunjukkan paling linear merupakan orde reaksi transesterifikasi.

\section{Hasil dan Pembahasan Ekstraksi Biji Buah Ketapang}


Pada proses ekstraksi biji buah ketapang diperoleh hasil seperti pada Tabel 2. Metode yang dipakai untuk mendapatkan minyak adalah dengan menggunakan metode Ekstraksi Soxhletasi, hal ini dikarenakan cara ekstraksi soxhletasi memiliki beberapa keunggulan diantaranya adalah (1) memerlukan pelarut yang sedikit yaitu hanya $3 / 4$ volume labu ekstraksi, (2) ekstraksi dapat berlangsung lebih efektif karena proses ekstraksinya berlangsung kontinyu dan dapat mengekstraksi senyawa secara maksimal dan (3) alatnya mudah dioperasikan.

Tabel 2. Hasil Ekstraksi Biji Buah Ketapang Menggunakan Metode Ekstraksi Sokletasi.

\begin{tabular}{|c|c|c|c|}
\hline No & $\begin{array}{c}\text { Berat Sampel } \\
(\text { gram })\end{array}$ & $\begin{array}{c}\text { Volume Pelarut } \\
\text { Petroleum Benzen } \\
(\mathrm{mL})\end{array}$ & $\begin{array}{c}\text { Volume } \\
\text { Minyak } \\
(\mathrm{mL})\end{array}$ \\
\hline 1 & 100 & 500 & 92 \\
\hline 2 & 100 & 500 & 77 \\
\hline 3 & 100 & 500 & 72 \\
\hline 4 & 100 & 500 & 90 \\
\hline 5 & 100 & 500 & 79 \\
\hline 6 & 100 & 500 & 64 \\
\hline 7 & 100 & 500 & 88 \\
\hline 8 & 100 & 500 & 88 \\
\hline 9 & 100 & 500 & 69 \\
\hline 10 & 100 & 500 & 70 \\
\hline 11 & 100 & 500 & 72 \\
\hline 12 & 100 & 500 & 74 \\
\hline 13 & 100 & 500 & 75 \\
\hline 14 & 100 & 500 & 72 \\
\hline 15 & 100 & 500 & 76 \\
\hline 16 & 100 & 500 & 71 \\
\hline 17 & 100 & 500 & 70 \\
\hline 18 & 100 & 500 & 1448 \\
\hline 19 & 100 & 500 & \\
\hline \multicolumn{5}{|l}{ Total minyak yang diperoleh } & 76 \\
\hline
\end{tabular}

Soxhletasi merupakan suatu cara ekstraksi yang menggunakan alat ekstraktor soxhlet dalam proses ekstraksinya. Alat soxhletnya terdiri dari beberapa bagian seperti labu tempat pelarut pengekstrak, tempat bahan yang diekstrak, shifon, dan kondensor. Dalam proses ekstraksinya pelarut akan menguap oleh pemanasan, selanjutnya uap akan naik ke kondensor melalui pipa samping. Oleh karena pada kondensor terdapat air dingin maka uap akan terkondensasikan dan akan menetes sebagai cairan. Cairan pelarut ini akan merendam bahan yang diekstraksi (proses ekstraksi), setelah cairan yang merendam setinggi shifon maka cairan pelarut yang sudah mengandung ekstrak akan tersirkulasi kembali ke labu. Pada labu akan mulai lagi proses pemanasan, pelarut akan menguap kembali menuju kondensor dan menetes sebagai cairan. Begitu seterusnya sampai sirkulasi terjadi berulang-ulang [11].

Oleh karena itu untuk ekstraksi minyak dari tumbuhan rata-rata menggunakan soxhlet. Sedangkan pelarut yang dipakai adalah petroleum benzen karena selain harganya murah dan mudah didapat juga memiliki titik didih yang rendah yakni berkisar antara $50 \mathrm{~s} / \mathrm{d} 60{ }^{\circ} \mathrm{C}$. Pada tahapan proses ekstraksi akan diperoleh banyak data, diantaranya waktu ekstraksi (menit), suhu ekstraksi $\left({ }^{\circ} \mathrm{C}\right)$, suhu destilasi hasil ekstraksi $\left({ }^{\circ} \mathrm{C}\right)$, berat sampel ketapang (gram), jumlah pelarut petroleum benzene yang digunakan (mL) serta jumlah minyak murni yang dihasilkan dalam ekstraksi (mL). Data-data ini yang akan membuktikan sempurna tidaknya suatu tindakan ekstraksi.

Metode sokletasi merupakan metode ekstraksi cara dingin. Selain itu metode ini memiliki beberapa kelebihan yakni secara kontinyu. Sampel biji buah ketapang yang akan diekstraksikan dihaluskan terlebih dahulu untuk memperbesar bidang kontak dengan pelarut. Pelarut yang digunakan dalam ekstraksi ini adalah petroleum bensen yang memiliki sifat kepolaran yang sama seperti minyak yaitu bersifat non polar, sehingga minyak dapat dengan mudah di peroleh karena keduanya saling melarutkan. Proses ekstraksi dilakukan selama 2 jam atau \pm 30 kali sirkulasi atau jika semua biji buah ketapang sudah terekstraksi oleh pelarut pada sokletasi. Kemudian didestilasi dan evaporasi untuk menghilangkan air yang masih bercampur dengan sampel.

Berdasarkan hasil penelitian penelitian yang diperoleh menunjukan bahwa dalam 100 gram sampel biji buah ketapang diperoleh minyak 60 mL-92 mL minyak (ekstraksi dilakukan sebanyak 19 kali untuk mendapat minyak sesuai dengan kebutuhan penelitian) atau kandungan minyaknya sekitar lebih dari $50 \%$. Total minyak yang diperoleh dari penelitian ini adalah 1.448 $\mathrm{mL}$ dari 1.900 gram biji buah ketapang.

\section{Transesterifikasi Minyak Biji Ketapang Menjadi Metil Ester}

Transesterifikasi (disebut alkoholisis) adalah pertukaran antara alkohol dengan suatu ester untuk membentuk ester lain pada suatu proses yang mirip dengan hidrolisis, kecuali pada penggunaan alkohol untuk menggantikan air dan menghasilkan produk samping yaitu gliserol.

Sebelum dilakukan proses pembuatan biodiesel perlu dilakukan pemurnian terhadap minyak/lemak. Minyak/lemak merupakan esterester asam lemak yang berasal dari alkohol tunggal, gliserol, $\mathrm{HOCH}_{2} \mathrm{CHOHCH}_{2} \mathrm{OH}$ dan dikenal sebagai gliserida [12]. Pemurnian yang dilakukan sangat sederhana yakni dengan menggunakan alat evaporator untuk menghilangkan sisa-sisa zat pengotor mislkan sisa kandungan air, tidak hanya sampai tahapan itu namun lebih dari itu minyak hasil ekstraksi dan perlakuan di alat evaporator selanjutnya ditambahkan natrium sulfat anhidrat yang bersifat mengikat air sehingga dapat dipastikan kandungan air yang masih tersisa dapat 
dihilangkan. Biasanya zat-zat pengotor dapat menyebabkan kualitas minyak kurang baik yang berdampak pada kualitas biodiesel yang juga kurang baik sehingga jika dipakai dalam pembakaran mesin diesel akan berpengaruh pada cepatnya kerusakan pada mesin diesel.

Tabel 3. Hasil Konversi Minyak Biji Ketapang Menjadi Metil Ester Untuk Suhu 30 oC dengan Waktu Selang 10, 20, 30, 40, 50, 60 menit.

\begin{tabular}{|c|c|c|}
\hline Waktu & Sampel yang & Warna \\
\hline 10 & 30 & Kuning \\
\hline 22 & 30 & Kuning \\
\hline 30 & 30 & Kuning \\
\hline 40 & 30 & Kuning \\
\hline 50 & 30 & Kuning \\
\hline 60 & 30 & Kuning \\
\hline $\begin{array}{l}\text { Total Volume } \\
\text { Minyak (mL) }\end{array}$ & \multicolumn{2}{|c|}{300} \\
\hline $\begin{array}{c}\text { Volume Metanol } \\
(\mathrm{mL})\end{array}$ & \multicolumn{2}{|c|}{84,6} \\
\hline $\begin{array}{l}\text { Berat } \mathrm{KOH} \\
\text { (gram) }\end{array}$ & \multicolumn{2}{|c|}{0,75} \\
\hline
\end{tabular}

Transesterifikasi juga menggunakan katalis dalam reaksinya. Tanpa adanya katalis, konversi yang dihasilkan maksimum namun reaksi berjalan dengan lambat [13]. Katalis berfungsi untuk mempercepat reaksi dengan menurunkan energy aktivasi reaksi namun tidak menggeser letak kesetimbangan. Tanpa katalis, reaksi transesterifikasi baru dapat berjalan pada suhu sekitar $250^{\circ} \mathrm{C}$. Penambahan katalis bertujuan untuk mempercepat reaksi dan menurunkan kondisi operasi. Katalis yang dapat digunakan adalah katalis asam, basa, ataupun penukar ion. Dengan katalis basa reaksi dapat berjalan pada suhu kamar, sedangkan katalis asam pada umumnya memerlukan suhu reaksi diatas $100^{\circ} \mathrm{C}$ [14]. Pada intinya, tahapan reaksi transesterifikasi pembuatan br didapatkan produk biodiesel dengan jumlah yang maksimum. Beberapa kondisi reaksi yang mempengaruhi konversi serta perolehan biodiesel melalui transesterifikasi adalah sebagai berikut [15]:

Berdasarkan Tabel 3, dapat dilihat minyak biji ketapang yang diperoleh melalui proses sokletasi direaksikan dengan metanol dan $\mathrm{KOH}$ sebagai katalis. Kemudian di dikonversi menjadi metil ester. Suhu yang digunakan dalam koversi minyak biji ketapang menjadi metil ester adalah $30{ }^{\circ} \mathrm{C}$ dengan variasi waktu tiap suhunya adalah 10 menit, 20 menit, 30 menit, 40 menit, 50 menit dan 60 menit.

Proses pembuatan biodiesel diawali dengan mengisi bejana dengan $500 \mathrm{~g}$ minyak ketapang dan dipanaskan sampai suhu $30^{\circ} \mathrm{C}$. Katalis $(\mathrm{KOH})$ dilarutkan dalam metanol pada bejana yang berbeda. Campuran katalis dan metanol dimasukkan ke dalam bejana minyak ketapang. Untuk menghindari terjadinya penguapan metanol, campuran katalis dan metanol dimasukkan langsung pada bagian bawah bejana minyak ketapang. Metil ester (biodiesel) sudah dapat diperoleh dengan pengambilan secara bertahap sebanyak $50 \mathrm{~mL}$ sampel dari dalam labu leher tiga pada selang waktu tertentu $(10,20,30$, 40, 50 dan 60 menit) kemudian untuk memisahkan dengan gliserol maka didiamkan selama 24 jam.

Setelah didiamkan selama 24 jam maka dipisahkan dengan corong pisah, kemudian diambil lapisan metil ester dengan menggunakan pipet dan dimasukkan ke dalam botol bersih yang telah disediakan sebanyak 6 botol sesuai suhu yang telah dilakukan. Fenomena yang dapat diamati bahwa ternyata dalam setiap botol akan terlihat dua lapisan yakni lapisan gliserol/gliserin yang berada di bagian bawah sedangkan metil seter berada pada lapisan atas, hal ini dikarenakan berat molekul gliserol lebih berat dari metil ester. Selain itu ciri fisik yang dapat diamati yaitu metil ester terlihat lebih jernih berwarna kuning sedangkan gliserol berwarna kabur gelap. Dengan demikian maka proses ini akan mengahasilkan hasil utama yang dinamakan metil ester (biodiesel) sebagai bahan bakar pada mesin diesel. Untuk lebih memurnikan lagi biodiesel maka ditambahkan lagi dengan natrium sulfat anhidrat dengan tujuan menghilangkan sisa air atau gliserol serta kemungkinan zat pengotor lainnya, karen sifatnya yang mengikat air. Setelah proses pemurnian kemudian disaring lagi sehingga diperoleh kemurnian biodiesel yang lebih murni. Metil ester yang terbentuk dari minyak biji ketapang memenuhi reaksi umum seperti Gambar 1.

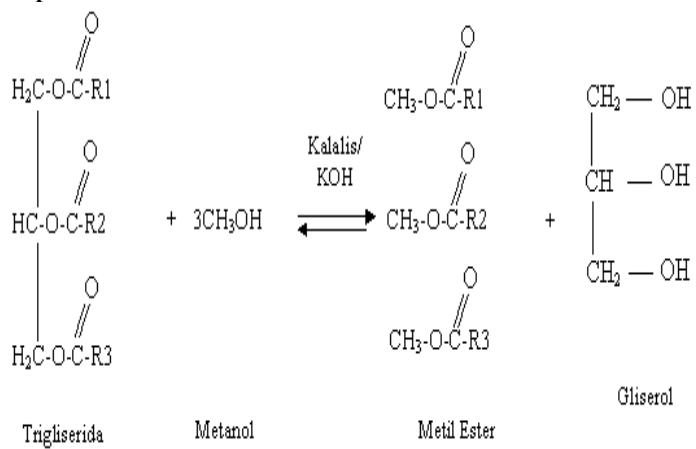

Gambar 1. Reaksi Transesterifikasi Minyak Biji Ketapang [16]. 


\section{Analisis Metil Ester Menggunakan Kromatografi Gas-Spektrofotometer Massa (GC-MS) \\ GC-MS merupakan penggabungan} instrumen antara kromatografi gas dan spektroskopi massa yang sering digunakan [17]. Pada metode GCMS cuplikan dimasukan ke dalam kromatografi gas dan terkromatografi sehingga semua komponennya terpisah. Spektrum diukur secara otomatis pada selang waktu tertentu, data yang dihasilkan berupa hasil kromatogram yang disertai dengan integrasi dari puncak- puncak sehingga diperoleh spektrum massa dari masing-masing komponen. Spektrum tersebut dapat digunakan untuk mengidentifikasi suatu senyawa tertentu karena diketahui berat molekul senyawa tersebut [18]. Metil ester yang dihasilkan dianalisis menggunakan GC-MS untuk mengetahui jumlah komponen senyawa dan jenis senyawa yang terkandung dalam metil ester.

\section{Untuk Suhu $30{ }^{\circ} \mathrm{C}$}

Perlakuan Suhu $30{ }^{\circ} \mathrm{C}$ pada Waktu 10 Menit. Untuk hasil GC-MS pada perlakuan suhu $30{ }^{\circ} \mathrm{C}$ dan waktu 10 Menit, dapat dilihat pada gambar 2.

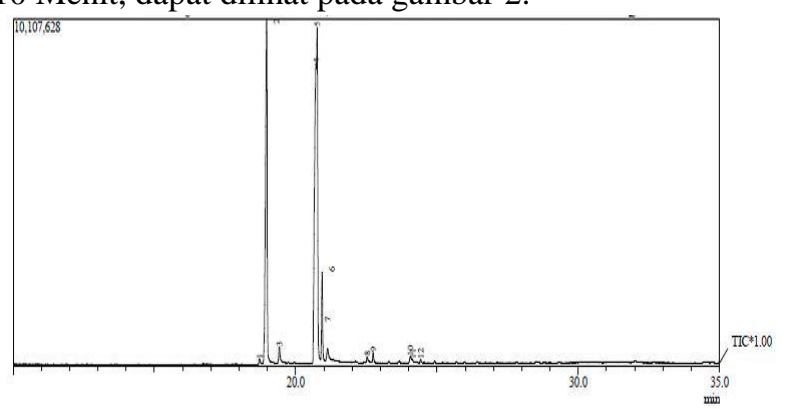

Gambar 2. Spektrum GC-MS Menit ke 10

Jumlah komponen yang terdeteksi seperti kromatogram GC adalah 12 puncak, berarti sampel yang diinjeksikan terdiri dari 12 senyawa. Senyawa ini keluarnya tidak bersamaan dari kolom karena satu sama lain memiliki titik didih yang berbeda. Senyawa yang meiliki titik didih paling rendah akan keluar paling cepat sedangkan senyawa dengan titik didih terbesar akan keluar paling akhir dari kolom. Disamping faktor titik didih perbedaan keluarnya dari kolom disebabkan oleh perbedaan afinitas kolom terhadap senyawa. Senyawa yang memiliki afinitas yang kuat terhadap kolom atau tertahan kuat oleh kolom akan keluar lebih lambat dari kolom. Senyawa yang keluar paling lambat dari kolom akan mempunyai waktu retensi yang paling besar. Tinggi puncak sebanding dengan konsentrasi komponen suatu senyawa dalam campuran sampel yang diinjeksi. Dari GC terlihat bahwa komponen senyawa terbesar adalah yang memiliki waktu retensi 18,974 menit $(34,52 \%)$, berikutnya adalah senyawa dengan waktu retensi 20,760 menit $(21,12$
$\%$ ) dan yang ketiga adalah senyawa dengan waktu retensi 20,718 menit (34,43\%) dan seterusnya.

Spektrum massa dalam GC-MS berfungsi sebagai detektor, setiap komponen yang keluar dari GC langsung ditembak dengan berkas elektron berenergi tinggi. Tembakan ini akan merubah molekul netral menjadi ion molekuler $\left(\mathrm{M}^{+}\right)$, ion molekuler akan berubah menjadi fragmen-fragmen. Fragmen yang paling stabil akan muncul sebagai puncak yang paling tinggi. Nilai $\mathrm{M}^{+}$menunjukan nilai massa molekul suatu senyawa.

Dari Spektrum MS dapat diketahui 12 senyawa yang terdeteksi oleh detektor spektrometer massa. Namun yang dibahas disini adalah 4 puncak saja yang memiliki persentase terbesar, yaitu puncak no 2, 4, dan 5. Puncak 2 ini adalah metil ester, metil palmitat ini ditandai dengan munculnya ion molekuler $\left(\mathrm{M}^{+}=270\right)$.

Puncak 2 adalah metil palmitat dengan persentase kemiripan dengan library (data base) $97 \%$ dan persentase dalam produk adalah 34,52 \%. Puncak 4 dan 5 juga merupakan metil ester, keduanya muncul dengan waktu retensi yang hampir sama. Namun dari data library (data base) sebenarnya puncak 4 dan puncak 5 adalah senyawa yang berbeda. Puncak 4 kemungkinannya adalah metil linoleat dengan kemiripan $89 \%$ ditandai dengan munculnya ion molekuler 294 persentase $(34,43$ $\%)$. Puncak 5 adalah metil oleat ditandai dengan munculnya ion molekuler 296 dengan kemiripan $80 \%$. Persentasenya dalam produk adalah 21,12 $\%$.

Perlakuan Suhu $30{ }^{\circ} \mathrm{C}$ pada Waktu 20 Menit. Untuk hasil GC-MS pada perlakuan suhu $30{ }^{\circ} \mathrm{C}$ dan waktu 20 Menit, dapat dilihat pada gambar 3 .

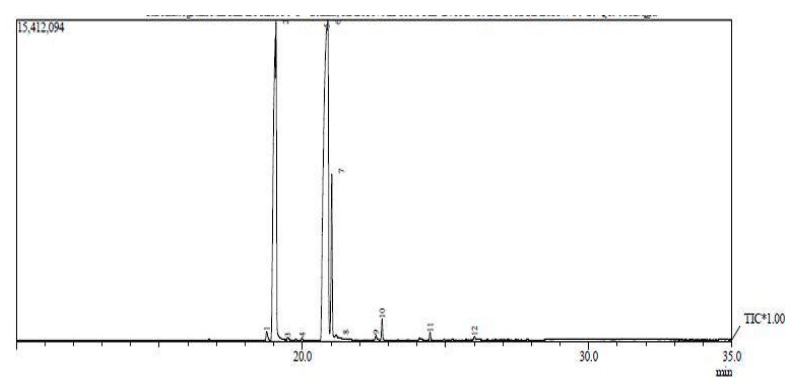

Gambar 3. Spektrum GC-MS Menit ke 20

Jumlah komponen yang terdeteksi seperti kromatogram GC adalah 12 puncak, berarti sampel yang diinjeksikan terdiri dari 12 senyawa. Senyawa ini keluarnya tidak bersamaan dari kolom karena satu sama lain memiliki titik didih yang berbeda. Senyawa yang meiliki titik didih paling rendah akan keluar paling cepat sedangkan senyawa dengan titik didih terbesar akan keluar paling akhir dari kolom. Disamping 
faktor titik didih perbedaan keluarnya dari kolom disebabkan oleh perbedaan afinitas kolom terhadap senyawa. Senyawa yang memiliki afinitas yang kuat terhadap kolom atau tertahan kuat oleh kolom akan keluar lebih lambat dari kolom. Senyawa yang keluar paling lambat dari kolom akan mempunyai waktu retensi yang paling besar. Tinggi puncak sebanding dengan konsentrasi komponen suatu senyawa dalam campuran sampel yang diinjeksi. Dari GC terlihat bahwa komponen senyawa terbesar adalah yang memiliki waktu retensi 19,078 menit $(35,84 \%)$, berikutnya adalah senyawa dengan waktu retensi 20,850 menit $(42,25 \%)$ dan yang ketiga adalah senyawa dengan waktu retensi 20,889 menit $(12,25 \%)$ dan seterusnya.

Spektrum massa dalam GC-MS berfungsi sebagai detektor, setiap komponen yang keluar dari GC langsung ditembak dengan berkas elektron berenergi tinggi. Tembakan ini akan merubah molekul netral menjadi ion molekuler $\left(\mathrm{M}^{+}\right)$, ion molekuler akan berubah menjadi fragmen-fragmen. Fragmen yang paling stabil akan muncul sebagai puncak yang paling tinggi. Nilai $\mathrm{M}^{+}$menunjukan nilai massa molekul suatu senyawa.

Dari Spektrum MS dapat diketahui 12 senyawa yang terdeteksi oleh detektor spektrometer massa. Namun yang dibahas disini adalah 4 puncak saja yang memiliki persentase terbesar, yaitu puncak no 2, 5, 6 dan 7. Puncak 2 ini adalah metil ester, metil palmitat ini ditandai dengan munculnya ion molekuler $\left(\mathrm{M}^{+}=270\right)$. Puncak 2 adalah metil palmitat dengan persentase kemiripan dengan library (data base) $97 \%$ dan persentase dalam produk adalah 35,50\%. Puncak 5 dan 6 juga merupakan metil ester, keduanya muncul dengan waktu retensi yang sama. Namun dari data library (data base) sebenarnya puncak 5 dan puncak 6 adalah senyawa yang berbeda. Puncak 5 kemungkinannya adalah metil linoleat dengan kemiripan $89 \%$ ditandai dengan munculnya ion molekuler 294 persentase $(42,58 \%)$. Puncak 6 adalah metil oleat ditandai dengan munculnya ion molekuler 296 dengan kemiripan $80 \%$. Persentasenya dalam produk adalah $12,25 \%$. Puncak 7 juga merupakan metil ester. Kemungkinan metil esternya adalah metil stearat dengan kemiripan $96 \%$, ditandai dengan munculnya ion molekuler sebesar 298 dengan persentase 6,95 $\%$.

Perlakuan Suhu $30{ }^{\circ} \mathrm{C}$ pada Waktu 60 Menit. Untuk hasil GC-MS pada perlakuan suhu 30 ${ }^{\circ} \mathrm{C}$ dan waktu 60 Menit, dapat dilihat pada gambar 4. Jumlah komponen yang terdeteksi seperti kromatogram GC adalah 9 puncak, berarti sampel yang diinjeksikan terdiri dari 9 senyawa. Senyawa ini keluarnya tidak bersamaan dari kolom karena satu sama lain memiliki titik didih yang berbeda. Senyawa ini keluarnya tidak bersamaan dari kolom karena satu sama lain memiliki titik didih yang berbeda. Senyawa yang memiliki titik didih paling rendah akan keluar paling cepat sedangkan senyawa dengan titik didih terbesar akan keluar paling akhir dari kolom. Di samping faktor titik didih perbedaan keluarnya dari kolom disebabkan oleh perbedaan afinitas kolom terhadap senyawa. Senyawa yang memiliki afinitas yang kuat terhadap kolom atau tertahan kuat oleh kolom akan keluar lebih lambat dari kolom. Senyawa yang keluar paling lambat dari kolom akan mempunyai waktu retensi yang paling besar. Tinggi puncak sebanding dengan konsentrasi komponen suatu senyawa dalam campuran sampel yang diinjeksi. Dari GC terlihat bahwa komponen senyawa terbesar adalah yang memiliki waktu retensi 20,922 menit $(53,95 \%)$, berikutnya adalah senyawa dengan waktu retensi 19,105 menit $(36,95 \%)$ dan yang ketiga adalah senyawa dengan waktu retensi 21,049 menit $(7,07$ $\%)$ dan seterusnya.

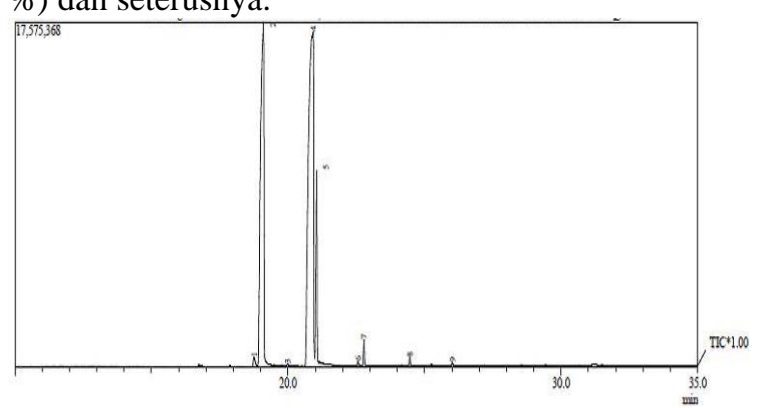

Gambar 4. Spektrum GC-MS Menit ke 60

Spektrum massa dalam GC-MS berfungsi sebagai detektor, setiap komponen yang keluar dari GC langsung ditembak dengan berkas elektron berenergi tinggi. Tembakan ini akan merubah molekul netral menjadi ion molekuler $\left(\mathrm{M}^{+}\right)$, ion molekuler akan berubah menjadi fragmen-fragmen. Fragmen yang paling stabil akan muncul sebagai puncak yang paling tinggi. Nilai $\mathrm{M}^{+}$menunjukan nilai massa molekul suatu senyawa.

Dari Spektrum MS dapat diketahui 9 senyawa yang terdeteksi oleh detektor spektrometer massa. Namun yang dibahas disini adalah 3 puncak saja yang memiliki persentase terbesar, yaitu puncak no 2, 4, dan 5. Puncak 2 ini adalah metil ester, metil palmitat ini ditandai dengan munculnya ion molekuler $\left(\mathrm{M}^{+}=270\right)$. Puncak 2 adalah metil palmitat dengan persentase kemiripan dengan library (data base) $95 \%$ dan persentase dalam produk adalah $36,95 \%$. Puncak 4 adalah metil oleat ditandai dengan munculnyaion molekuler 296 dengan kemiripan $95 \%$.Persentase dalam produk adalah 54,39\%. Puncak 5 juga merupakan metil ester. 
Kemungkinan metil esternya adalah metil stearat dengan kemiripan $96 \%$, ditandai dengan munculnya ion molekuler sebesar 298 dengan persentase 7,07 $\%$.

\section{Analisis Produk Metil Ester}

Penentuan Persentase Konversi Metil Ester Menggunakan H-NMR Penentuan konversi metil ester dianalisis dengan spectrometer ${ }^{1} \mathrm{H}-\mathrm{NMR}$. Puncak metoksi dari metil ester tampak pada $\pm 3,7$ ppm, dan puncak pada $\pm 4,2$ ppm merupakan tipe proton gliseril [11]. Puncak spektra HNMR akan mengalami pemecahan dipengaruhi oleh jumlah atom $\mathrm{H}$ tetangga. Jika tidak terdapat atom $\mathrm{H}$ maka disebut singlet yang berarti tidak terjadi pemecahan puncak. Satu atom $H$ disebut duplet dengan pemecahan puncak sebanyak 2 puncak. Demikian juga untuk triplet dan kuartet menunjukkan pemecahan puncak sebanyak 3 dan 4 [19]. Untuk perhitungan penentuan konversi metil ester, dapat diketahui melalui hasil spekturm H-NMR untuk suhu $30^{\circ} \mathrm{C}$ sebagai berikut. Spektrum H-NMR menit ke 10. Untuk hasil H-NMR pada perlakuan suhu 30 ${ }^{\circ} \mathrm{C}$ dan waktu 10 Menit, dapat dilihat pada gambar 5 . Untuk hasil H-NMR pada perlakuan suhu $30{ }^{\circ} \mathrm{C}$ dan waktu 20 Menit, dapat dilihat pada gambar 6.

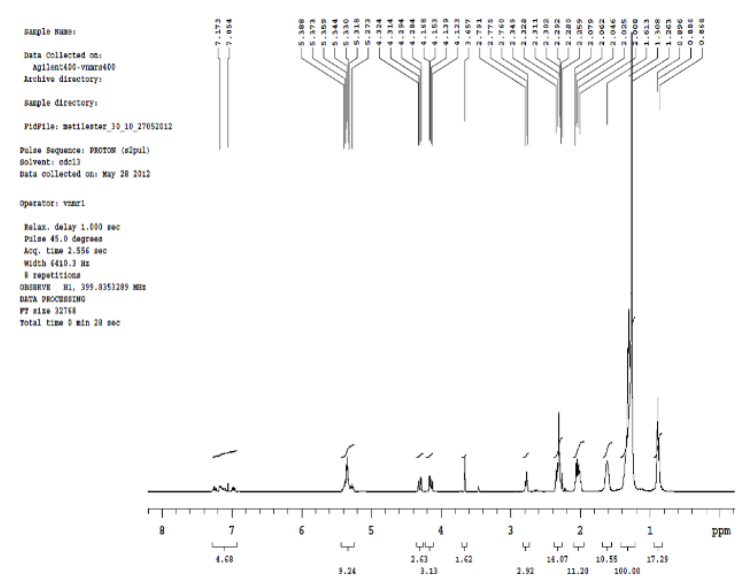

Gambar 5. Spektrum H-NMR Menit ke 10

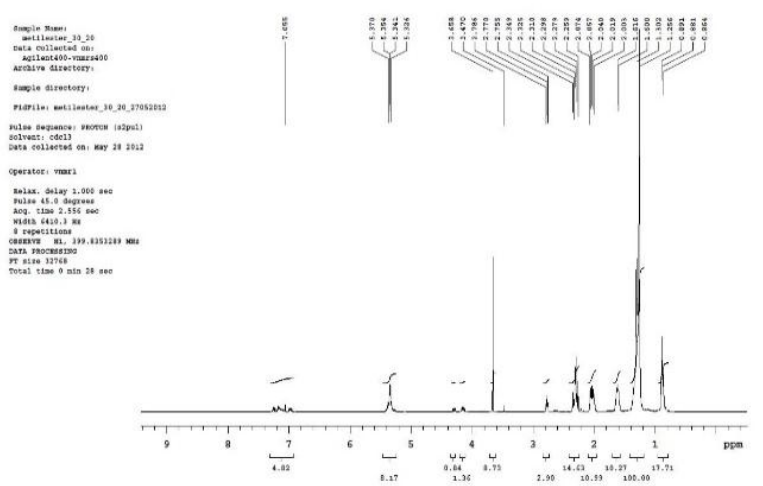

Gambar 6. Spektrum H-NMR Menit ke 20
Spektrum H-NMR menit ke 30

Untuk hasil H-NMR pada perlakuan suhu $30{ }^{\circ} \mathrm{C}$ dan waktu 30 Menit, dapat dilihat pada gambar 7 .

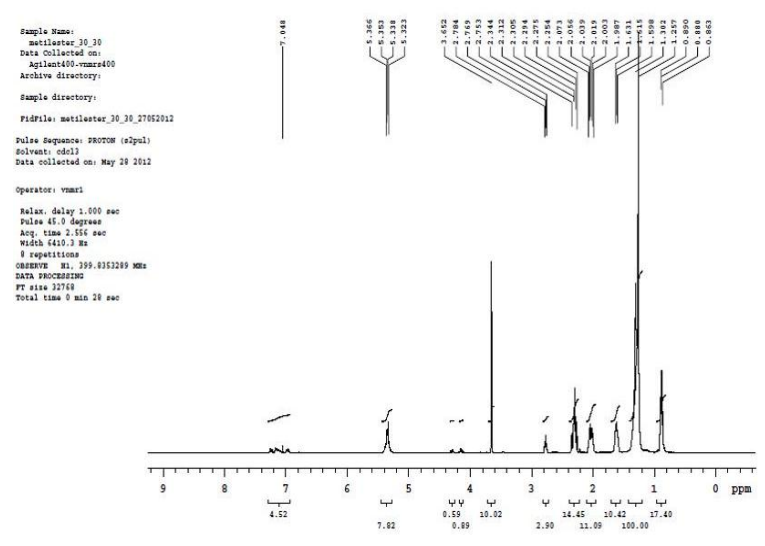

Gambar 7. Spektrum H-NMR Menit ke 30

4. Spektrum H-NMR menit ke 40

Untuk hasil H-NMR pada perlakuan suhu $30{ }^{\circ} \mathrm{C}$ dan waktu 40 Menit, dapat dilihat pada gambar 8 .

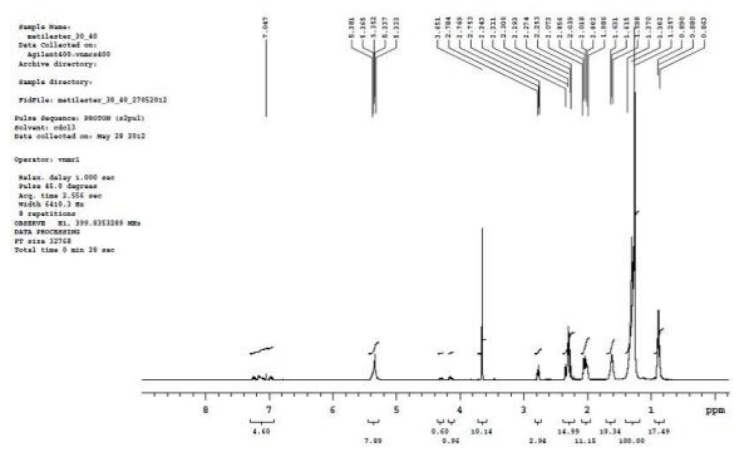

Gambar 8. Spektrum H-NMR Menit ke 40

5. Spektrum H-NMR menit ke 50

Untuk hasil H-NMR pada perlakuan suhu $30{ }^{\circ} \mathrm{C}$ dan waktu 50 Menit, dapat dilihat pada gambar 9.

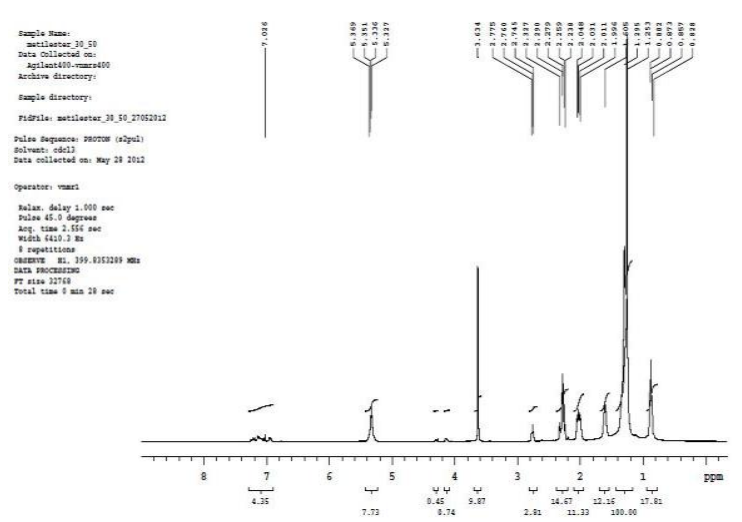

Gambar 9. Spektrum H-NMR Menit ke 50 
6. Spektrum H-NMR menit ke 60

Untuk hasil H-NMR pada perlakuan suhu $30{ }^{\circ} \mathrm{C}$ dan waktu 60 Menit, dapat dilihat pada gambar 10 .

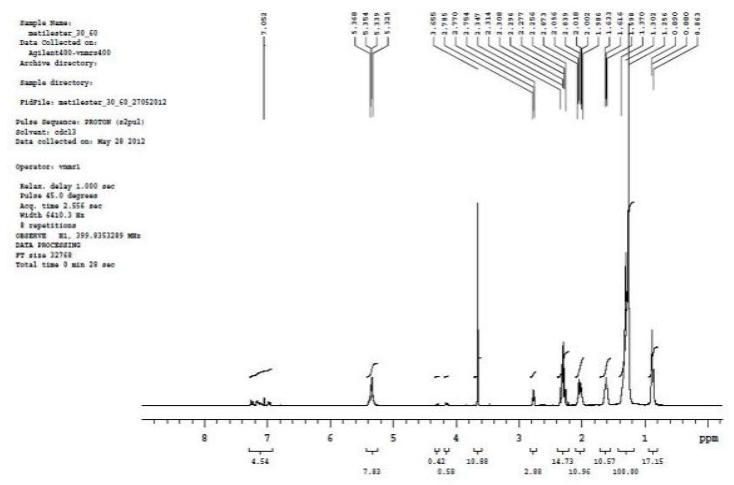

Gambar 10. Spektrum H-NMR Menit ke 60

Dari gambar di atas dapat dihitung hasil persentase konversi metil ester ditunjukan dalam tabel di bawah ini :

Tabel 5. Penentuan pesentase konversi metil ester Kinetika Reaksi Trasnesterifikasi

\begin{tabular}{|c|c|}
\hline \multirow{2}{*}{$\begin{array}{c}\text { Waktu } \\
\text { (menit) }\end{array}$} & $\begin{array}{c}\text { Kadar metil ester (CME) } \\
(\%)\end{array}$ \\
\cline { 2 - 2 } & $301 \mathrm{~K}$ \\
\hline 10 & 22,3 \\
\hline 20 & 78,09 \\
\hline 30 & 86,21 \\
\hline 50 & 85,43 \\
\hline 60 & 88,10 \\
\hline
\end{tabular}

\section{Kinetika Reaksi Trasnesterifikasi}

Kinetika reaksi merupakan cabang ilmu kimia yang membahas tentang laju reaksi dan faktor-faktor yang mempengaruhi. Laju reaksi dinyatakan sebagai perubahan konsentrasi pereaksi atau hasil reaksi terhadap satuan waktu. Laju rekasi suatu reaksi kimia dapat dinyatakan dengan persamaan laju reaksi. Untuk reaksi berikut:

$\mathrm{A}+\mathrm{B} \rightarrow \mathrm{AB}$

$\mathrm{R}=\mathrm{k}[\mathrm{A}]^{\mathrm{m}}[\mathrm{B}]^{\mathrm{n}}$

$\mathrm{k}$ sebagai konstanta laju reaksi, $\mathrm{m}$ dan $\mathrm{n}$ orde parsial masing-masing pereaksi [20-22].

Orde reaksi berkaitan dengan pangkat dalam hukum laju reaksi, reaksi yang berlangsung dengan konstan, tidak bergantung pada konsentrasi pereaksi disebut orde reaksi nol. Reaksi orde pertama lebih sering menampakkan konsentrasi tunggal dalam hukum laju, dan konsentrasi tersebut berpangkat satu. Rumusan yang paling umum dari hukum laju reaksi orde dua adalah konsentrasi tunggal berpangkat dua atau dua konsentrasi masingmasing berpangkat satu. Salah satu metode penentuan orde reaksi memerlukan pengukuran laju reaksi awal dari sederet percobaan. Metode kedua membutuhkan pemetaan yang tepat dari fungsi konsentrasi pereaksi terhadap waktu. Untuk mendapatkan grafik garis lurus [23].

Kinetika reaksi transesterifikasi dikaji dengan cara menguji data persentase trigliserida yang tidak terkonversi $\left(\mathrm{C}_{\mathrm{TG}}\right)$ pada persamaan hasil integrasi untuk masing-masing orde $0,1,2$ dan 3 melalui metode regresi linear.

Tabel 4. Penentuan pesentase $\mathrm{C}_{\mathrm{TG}}$

\begin{tabular}{|c|c|c|}
\hline \multirow{2}{*}{$\begin{array}{c}\text { Waktu } \\
\text { (menit) }\end{array}$} & $\begin{array}{c}\text { Kadar metil ester } \\
\left(\mathrm{C}_{\mathrm{ME}}\right)(\%)\end{array}$ & $\begin{array}{c}\mathrm{C}_{\mathrm{TG}}=100-\mathrm{C}_{\mathrm{ME}} \\
(\%)\end{array}$ \\
\cline { 2 - 3 } & $301 \mathrm{~K}$ & $301 \mathrm{~K}$ \\
\hline 10 & 22,3 & 77,7 \\
\hline 20 & 78,09 & 21,91 \\
\hline 30 & 86,21 & 13,79 \\
\hline 40 & 85,43 & 14,57 \\
\hline 50 & 88,10 & 11,9 \\
\hline 60 & 91,24 & 8,76 \\
\hline
\end{tabular}

Dari data tabel di atas dengan menggunakan regresi linear dapat di tentukan orde reaksi 0 adalah $\mathrm{r}^{2}=0,577982719$, untuk orde 1 adalah $\mathrm{r}^{2}=$ 0,771220455

Untuk orde 2 adalah $\mathrm{r}^{2}=0,919209092$, dan untuk orde 3 adalah $r^{2}=0,886125937$. Jadi pada suhu $30{ }^{\circ} \mathrm{C}$ reaksi transesterifikasi minyak biji ketapang menunjukan kesesuaian dengan kinetika reaksi orde 2 dengan nilai $\mathrm{a}=$ $4,536327234 \times 10^{-3}$ dan $b=1,764917475 \times 10^{-3}$. Seperti pada gambar 11 .

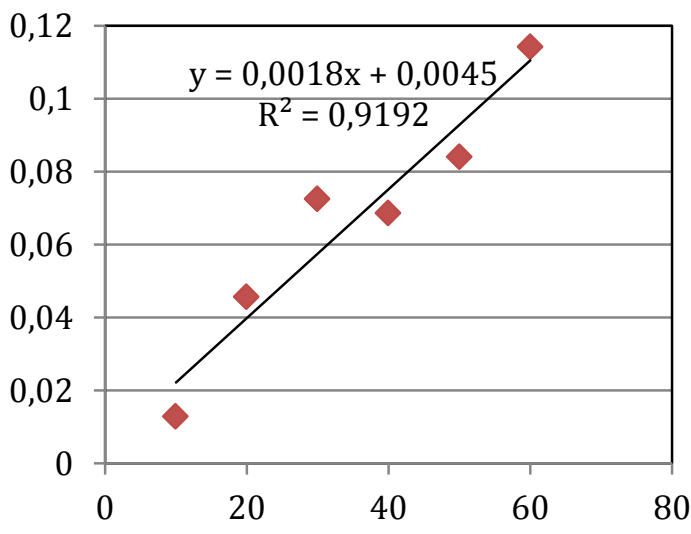

Gambar 11. Reaksi orde dua

\section{KESIMPULAN}

Berdasarkan hasil penelitian dapat disimpulkan bahwa persamaan laju reaksi transesterifikasi minyak biji ketapang menjadi metil ester yakni Sementara waktu ideal untuk suhu $30{ }^{\circ} \mathrm{C}$ dalam proses reaksi tranesterifikasi minyak biji ketapang pada proses produksi metil ester adalah 60 menit yang di tunjukan melalui grafik regresi linear pada reaksi orde 2 yaitu $r^{2}=0,919209092$. Dari gambar grafik di atas, konsentrasi yang paling tinggi berada pada waktu 60 menit. Hal ini 
menunjukan bahwa 60 menit merupakan waktu ideal dalam proses transesterifikasi minyak biji ketapang pada proses produksi metilester, dan dapat diperoleh persamaan laju reaksi transesterifikasi minyak biji ketapang.

\section{Daftar Pustaka}

[1] Carraretto, C., Macor, A., Mirandola, A., Stoppato, A., \& Tonon, S. (2004). Biodiesel as alternative fuel: Experimental analysis and energetic evaluations. Energy, 29(12-15), 2195-2211.

[2] Haas, M.J. (2005). Improving the economics of biodiesel production through the use of low value lipids as feedstocks: vegetable oil soapstock, Fuel Process Technol, 86, 1087-1096.

[3] Balogun, A. M. dan Fetuga, B. L. (1985). Fatty Acid Composition of Seed Oils of Some Membes of the Meliaceae and Combretaceae Families, JAOCS, Vol. 62, no. 3, Hal. 539 - 531.

[4] Agatemor, C. (2006). Studies of Selected Physicochemical Properties of Fluted Pumpkin(Telfairia occidentalis Hook F.) Seed Oil and Tropical Almond (Terminalia catappia L.)Seed Oil,Pakistan Journal of Nutrition5 (4) : 306 - 307.

[5] Fukada, H., Kondo, and Noda H. (2010). Biodiesel Fuel Production by Transesterifikasi of Oils. J. Biosci. Bioeng.

[6] Rachmaniah, O. (2004), Transesterifikasi Minyak Mentah Dedak Padi Menjadi Biodiesel Dengan Katalis Asam.Laporan Thesis, Jurusan Teknik Kimia FTI-ITS, Surabaya.

[7] Sudradjat, R., Sukardi, Mangunwidjaja, D., Suryani,A., Sahirman. (2008). Kinetika Reaksi Transesterifikasi Minyak Biji Nyamplung (Calophyllun inophyllum) Pada Proses Produksi Biodiesel, New York, Hancourt Brace \& Company.

[8] Huang, D., Zhou, H., \& Lin, L. (2012). Biodiesel: an alternative to conventional fuel. Energy Procedia, 16, 1874-1885.

[9] Suhendra, D., Gunawan, E. R., Nurita, A. D., Komalasari, D., \& Ardianto, T. (2017). Optimization of the enzymatic synthesis of biodiesel from Terminalia cattapa L. kernel oil using response surface methodology. Journal of oleo science, 66(3), 209-215.
[10] Yoeswono, Triyono and Tahir, I. (2008). Kinetics of Palm Oil Transesterification in Methanol with Possium Hydroxide as a Catalyst, Indo. J. Chem., 8 (2), 219-225.

[10] Hui, Y.H. (1996). Bailey's Industrial Oil and Fat Product. Vol 1, 5ed, pp, 46-53, John Wiley and Sons, New York.

[11] Widyastuti, C. R., \& Dewi, A. C. (2014). Sintesis Biodiesel Dari Minyak Mikroalga Chlorella Vulgaris Dengan Reaksi Transesterifikasi Menggunakan Katalis Koh. Jurnal Bahan Alam Terbarukan, 3(1), 2933.

[12] Riyanti, F., LH, P. L. P., \& DL, C. D. C. (2012). Pengaruh Variasi Konsentrasi Katalis $\mathrm{KOH}$ pada Pembuatan Metil Ester dari Minyak Biji Ketapang (Terminalia catappa Linn). Jurnal Penelitian Sains, 15(2).

[13] Mittlebach, M. and Remschmidt, C. (2004) Biodiesel The Comprehensive Handbook, Vienn, Boersedruck Ges.m.bH .

[14] Musta, R., Haetami, A., \& Salmawati, M. (2017). Biodiesel Hasil Transesterifikasi Minyak Biji Nyamplung (Calophyllum inophyllum) Dengan Metanol. Indo. J. Chem. Res., 4(2), 394401.

[15] Faizal, M., Noprianto, P., \& Amelia, R. (2009). Pengaruh Jenis Pelarut, Massa Biji, Ukuran Partikel dan Jumlah Siklus Terhadap Yield Ekstraksi Minyak Biji Ketapang. Jurnal Teknik Kimia, 16(2).

[16] Knothe, G. (2000). Monitoring a Progressing Transesterification Reaction by Fiber- Optic Near Infrared Spectroscopy with Correlation to ${ }^{1} \mathrm{H}$ Nuclear Magnetic Resonance Spectroscopy, J. Am. Oil Chem. Soc., 77, 9483, 489-493.

[17] Putri, N. P., Muslim, M. A., Sitorus, J. G., Putra, D. L., \& Marjenah, M. (2019). Extraction Of Ketapang Seeds (Terminalia Catappa Linn) As Raw Material Of Biodiesel. Konversi, 7(1), 1014.

[18] Ramadhani, D. G., Sarjono, A. W., Setyoko, H., Fatimah, N. F., \& Nurhayati, N. D. Synthesis of Natural $\mathrm{Ni} /$ Zeolite Activated by Acid as Catalyst for Synthesis Biodiesel from Ketapang Seeds Oil. JKPK (Jurnal Kimia dan Pendidikan Kimia), 2(1), 72-79. 
[19] Skoog, D.A., Holler, F.J \& Nieman, A.T. (1997). Principle of Instrumental Analysis, Fifth Edition, Departemen Teknologi Industri PertanianIPB, Bogor.

[20] Petrucci, Ralph H. (1987). Kimia Dasar Prinsip dan Terapan Modern Jilid 2, Erlangga, Jakarta.

[21] Siswani, E. D., Kristianingrum, S., Marwati, S., Noviantara, A., \& Yuniastuti, R. (2013). Pengaruh suhu dan waktu proses terhadap karakter biodiesel hasil sintesa dari minyak biji ketapang. Jurnal Sains Dasar, 2(2).

[22] Suwarso, W. P., Gani, I. Y., \& Kusyanto, K. (2008). Sintesis Biodiesel dari Minyak Biji Ketapang (Terminalia Catappa Linn.) yang berasal dari Tumbuhan di Kampus UI Depok. Jurnal Kimia Valensi, 1(2).

[23] Saputri, D., Fitriani, V. Y., \& Masruhim, M. A. (2013). Stabilitas Fisik dan Kimia Minyak Biji Ketapang (Terminalia catappa L.) Selama Penyimpanan. Journal of Tropical Pharmacy and Chemistry, 2(3), 132-145. 